\title{
Literature Review: Faktor-faktor Yang Berhubungan Dengan Gizi Kurang Pada Balita Usia 0-5 Tahun
}

\author{
Ilmiyah Nafi'ati ${ }^{1 *}$, Neti Mustikawati ${ }^{2}$ \\ ${ }^{1,2}$ Program Studi Sarjana Keperawatan dan Pendidikan Profesi Ners, Universitas Muhammadiyah \\ Pekajangan Pekalongan, Indonesia \\ *email: ilmiyahnafiati21@gmail.com
}

\begin{abstract}
The problem of malnutrition is still widespread in developing countries, including Indonesia. Malnutrition can limit the ability of individuals to reach their maximum potential. Factors that influence undernutrition need to be identified to reduce the number of undernourished children under five. To analyze the factors related to malnutrition in children aged 0-5 years. This study used a literature review method. The online database was used to search articles related to themes. Those were Google Scholar and PubMed. Articles were selected based on the suitability of keywords, topics and inclusion and exclusion criteria that have been determine. The results of this study showedthat there were 10 factors related to undernutrition in toddlers, namely parenting, mother's knowledge about nutrition, history of exclusive breastfeeding, age of toddlers, food intake, mother's perception of nutritional status, drinking water consumption, child's weight at birth, monitoring growth and development, and history of infectious diseases. The ten factors related to malnutrition in children under five were obtained from valid scientific evidence so that they can be used as scientific references to be applied as nursing care interventions.
\end{abstract}

Keywords: Undernourished children under five, Causative factors

\begin{abstract}
Abstrak
Masalah gizi kurang sampai saat ini masih tersebar di negara-negara berkembang termasuk negara Indonesia. Gizi kurang dapat membatasi kemampuan individu untuk mencapai potensi maksimalnya. Faktor yang mempengaruhi gizi kurang perlu diidentifikasi untuk mengurangi angka gizi kurang pada balita. Untuk menganalisis faktor-faktor yang berhubungan dengan gizi kurang pada balita usia 0-5 tahun. Penelitian ini menggunakan metode literature review. Database yang digunakan untuk pencarian artikel berkaitan dengan tema yang diambil dari beberapa search engine yaitu Google Scholar dan PubMed. Artikel diseleksi berdasarkan kesesuaian dengan kata kunci, topik serta kriteria inklusi dan ekslusi yang telah ditentukan. Hasil penelitian ini terdapat 10 faktor yang berhubungan dengan gizi kurang pada balita yaitu pola asuh, pengetahuan ibu tentang gizi, riwayat ASI ekslusif, usia balita, asupan makan, persepsi ibu tentang status gizi, konsumsi air minum, berat badan anak saat lahir, pemantauan tumbuh kembang, dan riwayat penyakit infeksi. Kesepuluh faktor yang berhubungan dengan gizi kurang pada balita ini didapatkan dari bukti ilmiah yang valid sehingga dapat dijadikan referensi ilmiah untuk diaplikasikan sebagai intervensi asuhan keperawatan.
\end{abstract}

Kata kunci: Balita gizi kurang, faktor penyebab.

\section{Pendahuluan}

Gizi merupakan bagian yang sangat penting untuk perkembangan dan pertumbuhan, terutama bagi usia balita. Gizi memiliki hubungan yang erat dengan status kesehatan dan kecerdasan otak, sehingga gizi menjadi penentu dalam kualitas sumber daya manusia [1]. Pada fase awal kehidupan atau 1000 hari pertama kelahiran bayi, status gizi dapat mempengaruhi tumbuh kembang anak saat usia dewasa dan 


\section{Prosiding Seminar Nasional Kesehatan Lembaga Penelitian dan Pengabdian Masyarakat Universitas Muhammadiyah Pekajangan Pekalongan}

memberikan dampak permanen atau irreversible[2]. Balita memerlukan gizi yang baik untuk membantu tumbuh kembangnya dan berperan dalam pembentukan fisik, psikis serta intelegensinya [3]. Balita dengan asupan gizi yang tidak seimbang dapat mengakibatkan berbagai masalah gizi.

Gizi kurang (underweight) merupakan gabungan dari gizi kurang dan gizi buruk, yang menjadi masalah kesehatan utama di Negara berkembang. Underweight merupakan indikator gizi kurang pada anak yang tidak membedakan antara kekurangan gizi jangka pendek dengan kekurangan gizi kronis [4]. Gizi kurang diakibatkan oleh kurangnya asupan nutrisi yang dibutuhkan tubuh. Kurangnya asupan nutrisi tersebut dapat menyebabkan berbagai macam penyakit. Mayoritas penderita gizi kurang yaitu anak usia di bawah lima tahun [1]. Selain gizi kurang, di Indonesia memiliki masalah gizi lebih.

Prevalensi underweight cenderung meningkat antara tahun 2010-2016, angka kejadian gizi kurang balita di Indonesia pada tahun 2017 sejumlah 17,8\% dan pada tahun 2018 mengalami penurunan menjadi 17,7\% [4]. Jumlah balita gizi kurang di Provinsi Jawa Tengah tahun 2017 17\%, tahun 2018 16,8\%. UNICEF memperkirakan jumlah balita yang mengalami kekurangan gizi dapat meningkat $15 \%$ secara global pada tahun 2020. Peningkatan angka gizi kurang pada balita lantaran banyak keluarga yang kehilangan pendapatan akibat pandemi. Hasil Riset Kesehatan Dasar dan Pemantauan Status Gizi overweight pada balita tahun 2016 4,3\% dan tahun 2017 $4,6 \%$. Angka gizi lebih pada balita mengalami peningkatan. Menurut Kementerian Kesehatan tahun 2018 pada kelompok anak usia di bawah lima tahun, prevalensi (BB/TB) menunjukkan tidak ada peningkatan, sebanyak $7 \%$ balita mengalami kegemukan [4]. Target WHA (2030) overweight pada balita mengalami penurunan drastis pada angka $<3 \%$.

Gizi kurang pada usia balita dipengaruhi oleh beberapa faktor, salah satunya faktor ekonomi. Faktor tersebut merupakan penentu dari status gizi balita. Status ekonomi yang rendah atau kemiskinan dapat menjadi penyebab utama gizi kurang. Faktor sosial ekonomi salah satunya meliputi pendidikan serta pendapatan keluarga. Faktor-faktor tersebut memiliki keterkaitan satu dengan yang lain, sehingga dapat mempengaruhi tumbuh kembang pada anak. Status pendidikan orang tua menjadi tolak ukur pengetahuan orang tua terhadap status gizi pada balita [19].

Berdasarkan penelitian yang dilakukan oleh Lestari Nina Dwi dengan judul Analisis Determinan Gizi Kurang Pada Balita di Kulon Progo, Yogyakarta pada jurnal Indonesia Journal of Nursing Practices didapatkan hasil faktor-faktor yang berhubungan dengan gizi kurang pada balita yaitu usia balita, riwayat pemberian ASI, asupan makanan, persepsi ibu terkait status gizi dan pola pengasuh keluarga terkait gizi. Hasil penelitian menunjukkan angka kejadian gizi kurang di wilayah Kulon progo masih cukup tinggi bila dibandingkan dengan data kejadian gizi kurang balita dalam cakupan wilayah Provinsi D.I.Y.

Penelitian terkait Faktor-Faktor Yang Berhubungan Dengan Gizi Kurang Pada Balita Usia 0-5 Tahun, secara komprehensif penelitian ini sudah banyak dilakukan untuk penelitian. Sehingga peneliti tertarik untuk melakukan penelitian dengan metode 


\section{Prosiding Seminar Nasional Kesehatan $\mathbf{2 0 2 1}$ Lembaga Penelitian dan Pengabdian Masyarakat Universitas Muhammadiyah Pekajangan Pekalongan}

literature review dalam menggambarkan faktor-faktor yang berhubungan dengan gizi kurang pada balita usia 0-5 tahun.

\section{Metode}

Penelitian ini menggunakan metode studi deskriptif melalui pendekatan literature review. Penelitian dilakukan dari bulan Januari sampai Juni 2021. Setelah menentukan topik penelitian, peneliti menggunakan beberapa strategi untuk melakukan pencarian artikel. Pemilihan kata kunci menggunakan bahasa Inggris dan bahasa Indonesia telah disesuaikan dengan topik. Database yang digunakan dalam penelitian adalah Google Scholar dan PubMed. Skrining artikel dilakukan dengan menggunakan filter yang ada pada database (tahun publikasi, full-text, dll.), serta seleksi baca cepat judul, topik, dan abstrak, artikel diseleksi kembali menggunakan kriteria inklusi dan eksklusi.

Kriteria inklusi dan eksklusi ditentukan berdasarkan tinjauan teori yang ada sebagai salah satu metode untuk mengeliminasi artikel yang telah ditemukan di database. Kriteria inklusi terdiri atasartikel yang membahas topik penelitian mengenai balita dengan gizi kurang, balita usia 0-5 tahun, artikel yang dipublikasikan pada tahun 2016-2021, artikel yang menggunakan metode penelitian kuantitatif, dan pencarian database sesuai dengan kata kunci. Sedangkan kriteria eksklusi pada penelitian ini yaitu artikel yang membahas lebih dari satu masalah gizi pada balita. Kelima artikel yang sudah diseleksi melalui kriteria inklusi dan kriteria ekslusi ditelaah kritis menggunakan instrumen strobe.

\section{Hasil dan Pembahasan Hasil}

Berdasarkan penelusuran search engine google schoolar, dan PubMed diperoleh 5 artikel yang direview sebagai berikut : Artikel pertama penulis Harianti \& Armayani dengan judul Analisis Faktor Determinan Kejadian Gizi Kurang Pada Balita Di Wilayah Pesisir Kelurahan Petoaha Kecamatan Nambo pada jurnal Miracle Journal of Public Health tahun 2019. Artikel kedua penulis Vina Novela \& Listiani Kartika dengan judul Faktor-Faktor Status Gizi Kurang Pada Anak Usia Prasekolah di Wilayah Kerja Puskesmas Guguk Panjang Kota Bukittinggi pada jurnal Endure : Kajian Ilmiah Problema Kesehatan tahun 2019.

Artikel ketiga penulis Nina Dwi Lestari dengan judul Analisis Determinan Gizi Kurang Pada Balita di Kulon Progo. Yogyakarta pada jurnal Indonesia Journal of Nursing Practices tahun 2016. Artikel keempat penulis Deepak, Adhikari, Dkk dengan judul Factors Associated With Underweight Among Under-Five Children In Eastern Nepal: Comminity-Based Cross-Sectional Study pada jurnal Frontiers in Public Healthtahun 2017. Artikel kelima penulis Esra Ratufalen,Dkk dengan judul Hubungan Pola Makan, Ekonomi Keluarga, dan Riwayat Infeksi Dengan Kejadian Gizi Kurang Pada Balita Di Wilayah Kerja Puskesmas Benu-Benua Tahun 2018.

1. Karateristik balita berdasarkan usia, jenis kelamin, dan status gizi.

Karateristik balita berdasarkan usia dapat di lihat pada tabel 3.1, Berdasarkan jenis kelamin dapat di lihat pada tabel 3.2, dan Berdasar kan Gizi dapat di lihat pada tabel 3.3. 


\section{Prosiding Seminar Nasional Kesehatan Lembaga Penelitian dan Pengabdian Masyarakat Universitas Muhammadiyah Pekajangan Pekalongan

Tabel 3.1 Karateristik Balita Berdasarkan Usia

\begin{tabular}{llll}
\hline & \multicolumn{2}{c}{ Artikel } & \multicolumn{1}{c}{ Usia } \\
\cline { 2 - 4 } No & Penulis & Tahun & $0-60$ bulan \\
\cline { 3 - 4 } & & $\mathrm{F}$ \\
\hline \multirow{2}{*}{1} & Harianti Armayani & 2019 & 62 \\
2 & Novela Vina,et.al & 2019 & 92 \\
3 & Lestari, Nina Dwi & 2016 & 155 \\
4 & Adhikari,et.al & 2017 & 300 \\
5 & Ratufelan,et.al & 2018 & 55 \\
\hline \multicolumn{3}{c}{ Total responden (n) } \\
\hline
\end{tabular}

Berdasarkan hasil literature review pada 5 artikel karateristik balita berdasarkan usia yaitu usia 0-60 bulan terdapat 664 responden.

Tabel 3.2 Karateristik Balita Berdasarkan Jenis Kelamin

\begin{tabular}{|c|c|c|c|c|c|c|}
\hline \multirow{3}{*}{ No } & \multicolumn{2}{|c|}{ Artikel } & \multicolumn{4}{|c|}{ Jenis Kelamin } \\
\hline & \multirow{2}{*}{ Penulis } & \multirow{2}{*}{ Tahun } & \multicolumn{2}{|c|}{ Laki-laki } & \multicolumn{2}{|c|}{ Perempuan } \\
\hline & & & $\mathrm{F}$ & $\%$ & $\mathrm{~F}$ & $\%$ \\
\hline 1 & Harianti Armayani & 2019 & 28 & 45,2 & 34 & 54,8 \\
\hline 2 & Novela Vina,et.al & 2019 & 54 & 58,7 & 38 & 41,3 \\
\hline 3 & Lestari, Nina Dwi & 2016 & 77 & 49,7 & 78 & 50,3 \\
\hline 4 & Adhikari,et.al & 2017 & 81 & 60,3 & 119 & 39,7 \\
\hline 5 & Ratufelan,et.al & 2018 & 26 & 47,3 & 29 & 52,7 \\
\hline & \multicolumn{2}{|c|}{ Total masing-masing usia } & 66 & 55,1 & 98 & 44,9 \\
\hline \multicolumn{3}{|c|}{ Total responden $(n)$} & & & 664 & \\
\hline
\end{tabular}

Berdasarkan tabel 3.2 menunjukkan bahwa dari 664 total populasi, karateristik responden berdasarkan jenis kelamin terbanyak yaitu laki-laki sejumlah $366(55,1 \%)$ responden dan paling sedikit yaitu perempuan sejumlah 298 (44,9\%) responden. 


\section{Prosiding Seminar Nasional Kesehatan Lembaga Penelitian dan Pengabdian Masyarakat Universitas Muhammadiyah Pekajangan Pekalongan}

Tabel 3.3 Karateristik Balita Berdasarkan Status Gizi

\begin{tabular}{ccccccc}
\hline & \multicolumn{3}{c}{ Artikel } & \multicolumn{4}{c}{ Status Gizi } \\
\cline { 2 - 7 } No & Penulis & Tahun & Baik & \multicolumn{3}{c}{ Kurang } \\
\cline { 2 - 7 } & & F & $\%$ & F & $\%$ \\
\hline 1 & Harianti Armayani & 2019 & 23 & 37,1 & 39 & 62,9 \\
2 & Novela Vina,et.al & 2019 & 52 & 56,5 & 40 & 43,5 \\
3 & Lestari, Nina Dwi & 2016 & 131 & 84,5 & 24 & 15,5 \\
4 & Adhikari,et.al & 2017 & 189 & 63 & 111 & 37 \\
5 & Ratufelan,et.al & 2018 & NM & NM & NM & NM \\
\hline \multicolumn{3}{c}{ Total masing-masing usia } & 395 & 64,9 & 214 & 35,1 \\
\hline \multicolumn{3}{c}{ Total responden (n) } & & & 609 \\
\end{tabular}

Berdasarkan tabel 3.3 menunjukkan bahwa karateristik responden berdasarkan status gizi baik sebanyak $395(64,9 \%)$ responden dan status gizi kurang sebanyak $214(35,1 \%)$ responden.

2. Karateristik ibu berdasarkan pendidikan ibu

Tabel 3.4 Karateristik Ibu Balita Berdasarkan Pendidikan Ibu

\begin{tabular}{|c|c|c|c|c|c|c|c|c|c|c|}
\hline \multirow{3}{*}{ No } & \multicolumn{2}{|l|}{ Artikel } & \multicolumn{8}{|c|}{ Pendidikan Ibu } \\
\hline & \multirow{2}{*}{ Penulis } & \multirow{2}{*}{ Tahun } & \multicolumn{2}{|c|}{$\begin{array}{l}\text { Tidak } \\
\text { Sekolah }\end{array}$} & \multicolumn{2}{|c|}{ Dasar } & \multicolumn{2}{|c|}{ Menengah } & \multicolumn{2}{|c|}{ Tinggi } \\
\hline & & & $\mathrm{F}$ & $\%$ & $\mathrm{~F}$ & $\%$ & $\mathrm{~F}$ & $\%$ & $\mathrm{~F}$ & $\%$ \\
\hline 1 & $\begin{array}{l}\text { Harianti } \\
\text { Armayani }\end{array}$ & 2019 & NM & NM & 52 & $\begin{array}{l}83 \\
9\end{array}$ & 7 & $\begin{array}{l}11 \\
3\end{array}$ & 3 & 4,8 \\
\hline 2 & $\begin{array}{l}\text { Novela } \\
\text { Vina,et.al }\end{array}$ & 2019 & 1 & 1,1 & 33 & $\begin{array}{l}35 \\
8\end{array}$ & 48 & $\begin{array}{l}52 \\
2\end{array}$ & 10 & $\begin{array}{l}10 \\
9\end{array}$ \\
\hline 3 & $\begin{array}{l}\text { Lestari, Nina } \\
\text { Dwi }\end{array}$ & 2016 & NM & NM & 58 & $\begin{array}{l}37, \\
4\end{array}$ & 97 & $\begin{array}{l}62 \\
6\end{array}$ & NM & NM \\
\hline 4 & $\begin{array}{l}\text { Adhikari,et.a } \\
\text { I }\end{array}$ & 2017 & 62 & $\begin{array}{l}20, \\
7\end{array}$ & 41 & $\begin{array}{l}13 \\
7\end{array}$ & 197 & $\begin{array}{l}65 \\
6\end{array}$ & NM & NM \\
\hline \multirow[t]{3}{*}{5} & $\begin{array}{l}\text { Ratufelan,et } \\
\text {.al }\end{array}$ & 2018 & NM & NM & 33 & 60 & 20 & $\begin{array}{l}36 \\
4\end{array}$ & 2 & 3,6 \\
\hline & $\begin{array}{r}\text { Total m } \\
\text { masing usia }\end{array}$ & asing- & 63 & 9,5 & 217 & $\begin{array}{l}32, \\
7\end{array}$ & 369 & $\begin{array}{l}55 \\
6\end{array}$ & 15 & 2,2 \\
\hline & $\begin{array}{l}\text { Total res } \\
\text { (n) }\end{array}$ & ponden & & & & & 66 & & & \\
\hline
\end{tabular}




\section{Prosiding Seminar Nasional Kesehatan 2021 Lembaga Penelitian dan Pengabdian Masyarakat Universitas Muhammadiyah Pekajangan Pekalongan}

Berdasarkan tabel 3.4 menunjukkan bahwa dari 664 total populasi, karateristik pendidikan ibu dibagi menjadi 4 kategori yaitu tidak sekolah, pendidikan dasar, pendidikan menengah, dan pendidikan tinggi. Jumlah responden yang tidak sekolah sebanyak 63 (9,5\%), responden dengan pendidikan dasar sebanyak $217(32,7 \%)$, responden dengan pendidikan menengah sebanyak $369(55,6 \%)$, dan responden dengan pendidikan tinggi sebanyak 15 (2,2\%). Karateristik pendidikan ibu yang paling banyak yaitu ibu dengan tingkat pendidikan menengah sebanyak 369 (55,6\%)

3. Faktor-faktor yang berhubungan dengan gizi kurang pada balita

Tabel 4.3 Faktor-Faktor Yang Berhubungan Dengan Gizi Kurang

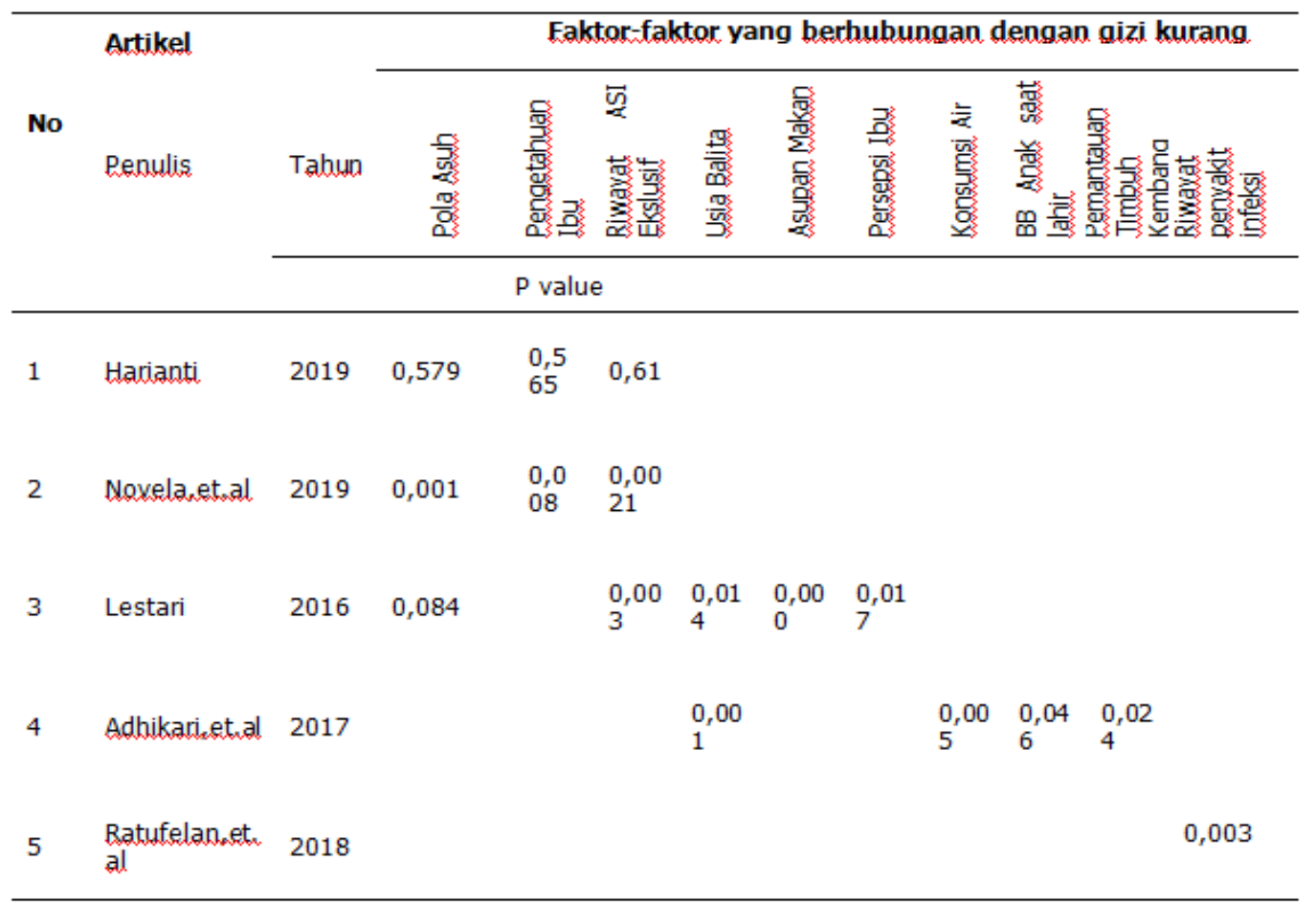

Berdasarkan tabel 4.3 diketahui ada 10 faktor-faktor yang berhubungan dengan gizi kurang pada balita yaitu pola asuh, pengetahuan ibu tentang status gizi, riwayat pemberian ASI ekslusif, usia balita, asupan makan, persepsi ibu tentang status gizi, konsumsi air, berat badan anak saat lahir, pemantauan tumbuh kembang, dan riwayat penyakit infeksi.

\section{Pembahasan}

Karateristik balita berdasarkan usia balita dari lima artikel yang di review yaitu balita dengan usia 0-60 bulan sejumlah 664 responden. Usia balita 0-5 tahun disebut sebagai periode Golden Age yaitu masa pertumbuhan dan perkembangan yang paling penting pada awal kehidupan anak. Pada periode ini pertumbuhan dan perkembangan anak perluh diperhatikan untuk mendeteksi adanya kelainan, sehingga apat meminimalisir kelainan pada perkembangan dan pertumbuhan yang bersifat permanen [5].Berdasarkan jenis kelamin balita dari kelima artikel yang di review jenis kelamin 


\section{Prosiding Seminar Nasional Kesehatan Lembaga Penelitian dan Pengabdian Masyarakat Universitas Muhammadiyah Pekajangan Pekalongan}

paling banyak yaitu laki-laki. Kejadian gizi kurang pada balita lebih banyak dialami oleh anak laki-laki mempunyai peluang untuk mengalami gizi kurang dibandingkan anak perempuan, karena anak laki-laki memerluhkan kalori lebih banyak untuk pertumbuhan dan perkembangan [6].Berdasarkan status gizi balita dari kelima artikel yang di review status gizi paling banyak yaitu balita dengan gizi baik. Status gizi baik menunjukkan bahwa anak berada pada kondisi status gizi yang optimal. Status gizi berpengaruh terhadap pertumbuhan dan perkembangan balita.

Karateristik ibu balita berdasarkan pendidikan ibu merupakan faktor yang penting dalam pemenuhan status gizi balita. tinggi rendahnya tingkat pendidikan ibu erat dengan pengetahuan terhadap kesehatan keluarga salah satunya status gizi anak. Tingkat pendidikan menentukan mudah tidaknya seseorang memahami pengetahuan gizi. Pendidikan gizi pada keluarga sangat dibutuhkan agar keluarga dapat mencegah atau bahkan dapat tanggap terhadap adanya masalah gizi dalam keluarga [3].

Faktor-faktor yang berhubungan dengan gizi kurang ada 10, yang pertama yaitu pola asuh. Pada artikel pertama, kedua dan ketiga menunjukan hubungan signifikan antara pola asuh dengan gizi kurang pada balita. Usia balita merupakan usia yang memiliki ketergantungan kepada orang tua dalam memenuhi kebutuh dasar. Seperti kebutuhan makan, kebutuhan membersihkan diri, rasa aman nyaman, dan mendapatkan kasih sayang. Kurangnya pola asuh pada balita dapat terjadi akibat ibu balita sering meninggalkan anak balitanya, sehingga ibu tidak pernah mendampingi anaknya saat makan. Kurangnya peran ibu saat menyiapkan dan mendampingi anak makan dapat mengakibatkan jam makan anak tidak teratur. Pola asuh makan yang baik tergantung pada orang tua yang mengajarkan kebiasaan makan-makanan yang sehat, bergizi, dan tepat waktu pada anak sejak anak kecil [7].

Faktor yang ke dua yaitu pengetahuan ibu. Pada artikel pertama dan kedua menunjukkan bahwa ada hubungan antara pengetahuan ibu dengan kejadian gizi kurang pada balita. Pengetahuan merupakan hasil tahu dari seseorang setelah melakukan penginderaan terhadap suatu objek tertentu. Melalui belajar, seseorang dapat mempunyai wawasan pengetahuan untuk mengubah perilaku sebelumnya. Pengetahuan ibu yang kurang tentang gizi memiliki dampak yang sangat berpengaruh terhadap status gizi balita sehingga dapat mengakibatkan masalah gizi bagi balita [8].Pengetahuan yang dimiliki ibu tergantung pada tingkat pendidikan yang diproleh baik formal ataupun informal, tingkat pendidikan dapat memberikan pengaruh seseorang dalam memahami suatu pengetahuan tentang status gizi dan kesehatan [9].

Faktor yang ke tiga yaitu riwayat pemberian ASI ekslusif. Pada artikel pertama, kedua dan ketiga terdapat hubungan yang signifikan antara riwayat pemberian ASI dengan status gizi balita dengan riwayat ASI nonekslusif berpeluang mengalami gizi kurang lebih besar dibandingkan dengan balita dengan riwayat ASI ekslusif.ASI memiliki komposisi yang seimbang dan sudah disesuaikan dengan kebutuhan balita sehingga ASI merupakan sumber gizi yang ideal. ASI merupakan makanan tunggal bagi bayi sampai usia 6 bulan, setelah usia 6 bulan bayi harus mulai diberi makanan padat atau mpasi [7].

Faktor yang ke empat yaitu usia balita. Pada artikel ketiga dan keempat usia balita terdapat hubungan yang signifikan. Usia anak 12-24 bulan termasuk dalam 


\section{Prosiding Seminar Nasional Kesehatan Lembaga Penelitian dan Pengabdian Masyarakat Universitas Muhammadiyah Pekajangan Pekalongan}

perkembangan kritis terutama pada perkembangan otak, sehingga membutuhkan makanan yang bergizi dan seimbang. Anak yang mengosumsi makanan tidak cukup zat gizinya dapat mengakibatkan gizi kurang pada anak [10].Balita dengan usia 12-36 bulan beresiko lebih besar mengalami gizi kurang. Usia balita yang masih muda menjadikan sistem kekebalan tubuh belum berkembang, hal ini menyebabkan balita lebih mudah mengalami masalah gizi [11].

Faktor yang ke lima yaituasupan makan. Berdasarakan artikel ketiga terdapat hubungan yang signifikan antara asupan makan dengan status gizi kurang pada balita. Asupan makan sangat mempengaruhi status gizi bagi setiap orang termasuk balita. Asupan makanan yang tidak seimbang, secara kualitas dan kuantitas dapat mengakibatkan kurangnya energi dan zat gizi yang dibutuhkan oleh tubuh balita untuk melaksanakan fungsinya [2].

Faktor yang ke enam yaitupersepsi ibu tentang status gizi. Berdasarkan hasil analisis pada artikel ketiga menunjukkan adanya hubungan yang signifikan antara persepsi ibu dengan status gizi pada balita. Persepsi merupakan suatu proses yang sebelumnya didahului oleh penginderaan atau biasa disebut dengan proses sensoris [12]. Orang tua yang memiliki persepsi kurang baik cenderung memiliki anak yang mengalami gizi kurang. Orang tua yang memiliki persepsi yang baik akan memanfaatkan tindakan pencegahan terhadap gizi kurang, dan membawanya ke fasilitas kesehatan [11].

Faktor yang ke tujuh yaitukonsumsi air. Pada artikel keempat terdapat hubungan yang signifikan antara konsumsi air dengan status gizi balita. Balita dengan keluarga yang mengkonsumsi air tanpa melalui proses pengolahan apapun seperti merebus, atau menyaring berisiko tinggi mengalami gizi kurang [13]. Balita yang mengosumsi air minum tanpa direbus dapat mengakibatkan terjadinya penyakit infeksi akibat kontaminasi air yang dikonsumsi. Air minum yang baik dan memenuhi syarat yaitu air minum yang tidak berwarna, air yang bersih, tidak berbau, dan tidak berasa [14].

Faktor yang ke delapan yaituberat badan anak saat lahir. Berdasarkan artikel keempat terdapat hubungan antara berat badan bayi baru lahir dengan status gizi kurang pada balita. Bayi yang lahir dengan berat badan kurang dari ukuran normal tergolong dalam Berat Badan Lahir Rendah (BBLR).. Bayi dengan berat badan lahir rendah cenderung mengalami masalah gizi dibandingkan dengan bayi dengan berat badan normal. Bayi dengan BBLR memiliki kekebalan tubuh yang terbatas, memungkinkan bayi rentan terhadap suatu infeksi. Bayi dengan BBLR umumnya saluran pencernaannya belum berfungsi dengan baik dari bayi yang cukup bulan, sehingga asupan makan tidak dapat diserap dengan baik oleh tubuh. Pertumbuhan dan perkembangan bayi BBLR dapat mengakibatkan status gizi kurang dan buruk lebih besar daripada bayi yang lahir dengan berat badan cukup [15].

Faktor yang ke sembilan yaitupemantauan tumbuh kembang. Berdasarkan hasil literature review pada artikel kelima menyatakan bahwa adanya hubungan pemantauan tumbuh kembang anak dengan status gizi balita yaitu pada artikel keempat. Balita yang tidak dipantau pertumbuhannya memiliki kemungkinan dua kali lebih besar mengalami gizi kurang dibandingkan balita yang dipantau [13].Pemantauan tumbuh kembang anak perlu diperhatikan oleh banyak pihak seperti orang tua dan 


\section{Prosiding Seminar Nasional Kesehatan Lembaga Penelitian dan Pengabdian Masyarakat Universitas Muhammadiyah Pekajangan Pekalongan}

pengasuh anak. Pihak tersebut harus mengetahui prinsip serta ciri-ciri tumbuh kembang pada anak sesuai usia anak. Pemantauan anak sangat diperlukan mulai anak berusia 0-72 bulan sampai anak masuk usia prasekolah. Kementerian Kesehatan RI 2016 telah membuat alat ukur untuk memantau perkembangan balita yaitu Pra Kuesioner Skrining Perkembangan (KPSP) [16]. Pemantauan dan perkembangan balita dapat dilakukan di posyandu setiap 3 bulan sekali untuk balita berusia dibawah 12 bulan, dan 6 bulan sekali untuk balita berusia diatas 12 bulan [16].

Faktor yang ke sepuluh yaituriwayat penyakit infeksi. Berdasarkan wawancara responden menggunakan kuesioner pada artikel kelima terdapat hubungan yang bermakna antara riwayat penyakit infeksi dengan kejadian gizi kurang pada balita di wilayah kerja puskesmas benu-benua. Penyakit infeksi yang menyerang balita secara langsung dapat berpengaruh terhadap status gizi balita. Balita yang mengalami penyakit infeksi dapat menyebabkan tubuh balita tidak dapat menyerap makanan secara baik sehingga mengakibatkan masalah gizi pada balita [17]. Riwayat penyakit infeksi merupakan suatu keadaan dimana seseorang pernah menderita suatu penyakit infeksi. Penyakit infeksi dapat menyebabkan nafsu makan menjadi menurun, balita yang mengalami penyakit infeksi cenderung mengalami penurunan berat badan, hal tersebut terjadi karena peningkatan metabolisme dalam tubuh dan biasanya disertai nafsu makan menurun. Penurunan berat badan yang terus menerus dapat mengakibatkan terjadi penurunan gizi sehingga menyebabkan gizi kurang [18].

\section{Kesimpulan}

Berdasarkan hasil review dari 5 artikel, karateristik balita meliputi usia, jenis kelamin, dan status gizi dengan jumlah populasi 664 responden, usia balita terbanyak yaitu rentang usia 37-60 bulan sejumlah $350(57,5 \%)$ responden, jenis kelamin balita terbanyak yaitu laki-laki sejumlah $366(55,1 \%)$ responden, dan status gizi balita terbanyak yaitu status gizi baik sejumlah 395 (64,9\%) responden. Karateristik ibu balita meliputi pendidikan ibu didapatkan hasil mayoritas pendidikan ibu yaitu pendidikan menengah sejumlah $369(55,6 \%)$ responden. Dan didapatkan 10 faktor yang berhubungan dengan gizi kurang pada balita, yaitu pola asuh, pengetahuan ibu tentang status gizi, riwayat pemberian ASI ekslusif, usia balita, asupan makan, persepsi ibu tentang status gizi, konsumsi air, berat badan anak saat lahir, pemantauan tumbuh kembang, dan riwayat penyakit infeksi.

\section{Referensi}

[1] Hasdianah, S. Siyoto, dan Nurwijayanti, Gizi Pemanfaatan Gizi, Diet, dan Obesitas. Yogyakarta: Nuha Medika, 2017.

[2] S. Fikawati, A. Syafiq, dan A. Veratamala, Gizi Anak dan Remaja. Depok: PT RAJAGRAFINDO PERSADA, 2017.

[3] Y. A. Rias, Nutrisi Sang Buah Hati Bukti Cinta Ibu Cerdas. Yogyakarta: Gosyen Publishing, 2016.

[4] F. Watson, Minarto, S. Sukotjo, J. H. Rah, dan A. K. Maruti, Pembangunan Gizi di Indonesia. Jakarta: Kementerian PPN / Bappenas, 2019.

[5] L. PH, Hermanto, dan Pranita, "Karakteristik Orang Tua Dan Perkembangan 


\section{Prosiding Seminar Nasional Kesehatan $\mid 2021$ \\ Lembaga Penelitian dan Pengabdian Masyarakat Universitas Muhammadiyah Pekajangan Pekalongan}

Psikososial Infant," J. Kesehat., vol. 12, hal. 1-13, 2019.

[6] R. Addawiah, O. Hasanah, dan H. Deli, "Gambaran Kejadian Stunting Dan Wasting Pada Bayi Dan Balita Di Tenayan Raya Pekanbaru," J. Nutr. Coll., vol. 9, hal. 228-234, 2020.

[7] V. Novela dan L. Kartika, "Faktor-Faktor Status Gizi Kurang Pada Anak Usia Prasekolah di Wilayah Kerja Puskesmas Guguk Panjang Kota Bukittinggi," J. Endur., vol. 4, no. 2, hal. 359, 2019, doi: 10.22216/jen.v4i2.4021.

[8] M. Susanti, Faktor-Faktor yang Berhubungan Dengan Status Gizi Balita di Kelurahan Bumijo Kecamatan Jetis Kota Yogyakarta Tahun 2017. 2018.

[9] asma atun nisa Saparudin, "Hubungan Tingkat Pengetahuan Ibu Tentang Status Gizi Dengan Status Gizi Pada Balita Di Puskesmas Tegalrejo Kota Yogyakarta," 2017.

[10] A. Istiany dan Rusilanti, Gizi Terapan. Bandung: PT REMAJA DOSDAKARYA, 2013.

[11] N. D. Lestari, "Analisis Determinan Gizi Kurang pada Balita di Kulon Progo, Yogyakarta," Indones. J. Nurs. Pract., vol. 1, no. 1, hal. 15-21, 2016.

[12] K. M. Putri, "Hubungan Pengetahuan Dan Persepsi Dengan Status Gizi Balita Di Puskesmas Paal Merah Kota Jambi Tahun 2017," J. Kebidanan, vol. 7, hal. 1-9, 2018.

[13] D. Adhikari, R. B. Khatri, Y. R. Paudel, dan A. K. Poudyal, "Factors Associated with Underweight among Under-Five Children in Eastern Nepal: CommunityBased Cross-sectional Study," Front. Public Heal., vol. 5, no. December, hal. 1-9, 2017, doi: 10.3389/fpubh.2017.00350.

[14] R. Simbolon, "Hubungan Faktor Sosial Ekonomi dan Higiene Sanitasi Lingkungan dengan Status Gizi Anak Balita di Desa Nifuboke Tahun 2016," J. INOHIM, vol. 5, no. 2, hal. 96, 2017, [Daring]. Tersedia pada: https://inohim.esaunggul.ac.id/index.php/INO/article/view/133.

[15] N. K. Dewi dan H. Widyasih, "Kejadian Bayi Berat Lahir Rendah Dan Status Gizi Balita," J. Kesehat., vol. 7, hal. 59-63, 2015.

[16] R. M. Kusuma, "Hubungan Status Gizi dengan Perkembangan Anak Umur 24-60 Bulan di Kelurahan Bener Kota Yogyakarta," J. Kesehat. Vokasional, vol. 4, no. 3, hal. 122, 2019, doi: 10.22146/jkesvo.46795.

[17] E. A. Z. J. Ratufelan, "Hubungan Pola Makan, Ekonomi Keluarga dan Riwayat Infeksi dengan Kejadian Gizi Kurang pada Balita di wilayah Kerja Puskesmas Benu-Benua Tahun 2018," J. Ilm. Mhs. Kesehat. Masy., vol. 3, no. 2, hal. 3, 2018, [Daring]. Tersedia http://ojs.uho.ac.id/index.php/JIMKESMAS/article/view/4017.

[18] E. G. Cono, M. P. M. Nahak, dan A. M. Gatum, "Hubungan Riwayat Penyakit Infeksi Dengan Status Gizi Pada Balita Usia 12-59 Bulan Di Puskesmas Oepoi Kota Kupang," CHMK Heal. J., vol. 4, no. April, hal. 0-7, 2020.

[19] P.A. Ariani. "Ilmu Gizi". Yogyakarta: Nuha Medika. 2017. 